\title{
研究課題別事後評価結果
}

1. 研究課題名:セキュリティ向け超高感度匂いセンサシステムの開発

2. 研究代表者名及び主たる研究参加者名 (研究機関名・職名は研究参加期間終了時点)：

研究代表者＼cjkstart都甲 潔(九州大学大学院 システム情報科学研究院 主幹教授)

共同研究者李 丞祐 (北九州市立大学国際環境工学部 准教授)

\section{3. 研究実施概要}

武器密輸やテロ防止などに向けた爆発物検出の既存装置として現在、据え置き型のX線型や質量分析型爆 発物探知装置が用いられているが、トータルにデザインされたものは存在しない。また可搬型の既存の爆発物 探知装置は感度不足や誤警報が多く、実際の現場では使えないものがほとんどである。

これらの課題を解決するために、本研究は、目的分子と選択的に結合する抗体および鋳型分子認識膜を、そ れぞれ表面プラズモン共鳴 (SPR: Surface Plasmon Resonance)センサおよび電気化学センサとを組み合わ せ、イヌの鼻を超える ppt(parts per trillion)レベルの検出感度を有する可搬型の超高感度匂いセンサシステ ムの開発を目的としている。

基本技術は抗原抗体反応の利用であり、抗体が製作可能であれば抗体を利用し、抗体が製作できない物質 は分子鋳型法により対応する。開発装置は収集部、濃縮・捕集部、検出部から構成され、検查物質の収集方法 に「吸い込み式」と「拭き取り式」があるが、早期導入第 1 ステップとして「拭き取り式」の測定精度や測定時間に ついての分析検討、試作・実証確認を行なった。並行して「吸い込み式」の基本方式の検討と試作確認を行っ た。

科学警察研究所から爆薬付着量の知見が得られ，その状況を想定し高感度検出を行った。

測定精度に関しては、TNT についてワイパーによる拭き取り実験で、回収率は $10 \sim 30 \%$ 、数 $10 \mathrm{ppb}$ (parts per billion)の溶液が得られた。この抽出濃度は検出下限よりも大幅に高く、実際に付着する微 量の TNT が検出可能である見通しが得られた。また、TNT の分解生成物として TNT より高濃度で存在し、爆 薬に使われるDNT(Di Nitro Toluene)について、間接競合法による感度増幅により 20 ppt の検出下限が得 られた。さらに軍用爆薬に使用される RDX (Research Department Explosive)について、間接競合 ELISA (Enzyme-Linked Immunosorbent Assay:酵素免疫測定)法による感度増幅により、サブ ppb の検出下限が 得られた。すなわち TNT、DNT に対して pptレベル、RDXに対してサブ ppbレベルの超高感度測定が可能 である知見を得た。

測定時間に関しては、置換法により時間短縮を図り、1 分間の TNT 流通で、検出下限 $0.9 \mathrm{ppb}$ を達成した。 また、TNT 流通 10 秒後のセンサ応答の傾き(微分值) とリファレンスの応答との比を取る方法により、検出下限 $0.7 \mathrm{ppb}$ で検出可能とし、10 数秒で TNT の検出が可能な知見を得た。

これらの知見のもとに、応用開発として、テロのターゲットとされやすい空港や駅構内等の公共施設での探知 を想定し、可搬型約 $10 \mathrm{~kg}$ のPR 計測センサの試作を行った。適用したセンシング手法で TNT に対して間接 競合法により検出下限が数 pptを実現し、より短時間測定が可能な置換法では、数 100 pptレベルを数十秒で 実現、実用の見通しを得た。

このように爆薬探知に関する基礎技術が揃い、平成 22 年 1 月に財務省関税中央分析所において、「拭き取り 式」による実証試験を行い、科学警察研究所提示の爆薬付着状況での試験の結果、サンプリングから検出まで の目標1分以内の検出が達成できた。一方「吸い込み式」は、実用化ネックとなるサンプリングの検証実験の結 果、目標である約 $1 \mathrm{ppb}$ の濃度の TNT 溶液が得られ、基本方式が確認できたが、サンプリングに約 8 分を要し ており、実用化に向けては、さらに濃縮時間の短縮と濃縮効率の向上が必要である。今後これまでの成果と知 見を基に、実用化に向けた取組みを行なう予定である。

\section{4. 事後評価結果}

4-1. 研究の達成状況及び得られた研究成果 (論文・口頭発表等の外部発表、特許の取得状況等を含む)

本研究では、匂いの中でも爆薬成分に絞り、TNT、DNT、RDX 等を検出するセンサを開発し、空港や警察 において爆薬検出に使えることを示した。根幹技術は爆薬分子の部分構造を認識する抗体の製作技術であり、 SPR 計測センサを用いて爆薬に対して高い特異性を持つ抗原抗体反応に注目したことは独創的で、それを確 立した業績は大きい。抗原抗体反応型 SPR 計測センサの性能は、優れたものである。 
第1ステップとして「拭き取り式」による、SPR 計測検出感度 $1 \mathrm{ppb}$ 、トータル測定時間 1 分のポータブル SPR 計測センサ試作機を完成させ、財務省関税中央分析所での実証試験で目標を達成し、社会実装が可能な見 通しが得られたが、当初の「吸い込み式」については、実用化のネックとなるサンプリングの検証実験に留まって おり、幅広い社会実装に向けた「センサシステム」の開発目標に向けて、より利便性に優れるシステムの追求が 必要である。

研究開発は、都甲研究代表グループがセキュリティ用途向け超高感度匂いセンサの開発と研究チームの総 括を担当し、李共同研究者グループが爆薬および爆薬マーカーに対する鋳型分子認識膜の作製を担当して、 実施された。

成果発表については、論文は下記の通り多く出されており、学会表彰やマスコミ報道もされているが、特許は 国内1件の出願で少ない。この分野はノウハウを開示しない方が望ましいのかも知れないが、試作したシステム が模倣されないような防衛策も必要であり、組み合わせ技術でも特許になる可能性はあるので、引き続き特許化 の検討が必要である。

原著論文:国内(和文)誌 1 件, 国際(欧文)誌 15 件

学会発表:招待講演：（国内会議 9 件, 国際会議 4 件)

口頭講演：（国内会議 20 件, 国際会議 13 件）

ポスター発表：(国内会議 13 件, 国際会議 8 件)

知財出願：国内出願 (1件)

受賞：都甲 潔, 応用物理学会 フェロー表彰, 感性バイオセンサーの開発 (2008)

4-2. 研究成果の科学技術や社会へのインパクト、戦略目標への貢献

本研究では、優れた性能のセンサが実現されており、研究成果のレベルは高く技術的なインパクトは強いが、 得られた技術が現場でどのように役立ち、幅広い社会実装のインパクトとなるかは実証実験や生産技術の進展 がポイントとなる。サンプリングの自動化や計測時間の短縮など実用化に向けての課題は残されているが、爆薬 の検出法として財務省関税中央分析所とで得られた実証実験の成果が空港等の現場に導入されれば、インパ クトのあるシステム構築に繋がる。また本技術は爆薬以外にも適用可能であり、戦略目標である安全安心の 様々な用途で応用展開が考えられる。

本研究で確立された TNT、DNT、RDX 産生ハイブリドーマ細胞(抗体産生細胞) は、九州大学の有体物管 理センターに登録されており、同センターを通じて、所定の手続きを行えば、一般に利用可能となる見込みであ り、社会還元にも貢献している。

\section{4-3. 総合的評価}

本研究は国家的・社会的重要性が高い爆発物テロや犯罪など危機管理に関する取組みであり、SPR 計測法 によるコンパクトな計測装置の開発は、独創的な成果であり、海外の技術に比べて類似の技術が見当たらない 点で評価される。

研究開発は、実用に向けて着実に進められ、「拭き取り式」では、財務省関税中央分析所と連携した実証実 験に結び付け、成果をあげた。なお当初目標とした、より汎用的で利便性のよい「吸い込み式」については、実 用に向けたさらなる進展が必要である。これらの得られた技術をべースに、現場でじのように役立つものなのか について実証実験からの知見による改良や生産技術の進展により、幅広い社会実装に繋がる。

本研究の成果が空港や警察を含め、広く民生的なセキュリティ業務に使われる分野の実用化につなげ、世界 に広めて欲しい。本研究の根幹技術である抗体の製作技術の適用対象の拡大により、爆薬以外にも麻薬や細 菌、食品への応用範囲を広げることが可能であり、今後のそれらの展開にも期待する。

以上 